\title{
ACCESS TO JUSTICE VS ACCESS TO JUSTICE FOR SMALL AND MEDIUM-SIZED ENTERPRISES: THE CASE FOR A BILATERAL ARBITRATION TREATY
}

\author{
Petra ButLER* AND CAMPBELL HERBERT***1
}

The growth of businesses in New Zealand is constrained by the relatively small size of the New Zealand market. Expansion into foreign markets is therefore critical for business growth. However, businesses - small and medium-sized enterprises in particular - trading across multiple jurisdictions face barriers to accessing justice when disputes arise. Because of these barriers businesses are dissuaded from engaging in international trade, even though to do so would be beneficial for both the businesses and the economy generally. The proposed solution is to reduce barriers to accessing justice through a Bilateral Arbitration Treaty: a treaty which supplants the existing systems of cross border litigation, replacing it with a dispute resolution mechanism resembling international commercial arbitration. This article explains the proposal by Gary Born, and the ways in which such a dispute resolution mechanism would serve to enhance access to justice, especially for small and medium enterprises in New Zealand.

\section{INTRODUCTION}

Small and medium-sized enterprises ("SMEs”) are the predominant business form in New Zealand. ${ }^{2}$ Of New Zealand enterprises, 97 per cent are small businesses $^{3}$ and a further 2 per cent are medium-sized enterprises. ${ }^{4}$ Three hundred and twenty-six thousand small businesses, approximately 69 per cent of the total number of businesses operating in New Zealand, have no staff beyond the founder or owner, ${ }^{5}$ but overall these companies employ close to

* $\quad$ LLM Well, Dr Jur Gött. Associate Professor, Victoria University of Wellington

** LLB (Hons), BCom Well. Solicitor, Chapman Tripp.

1 The authors would like to offer their thanks to Asher Emanuel for his helpful research assistance; to the anonymous reviewer and Professor Tony Angelo for their invaluable comments on the draft of this article. A special thank you is due to Gary Born for making the draft of his Bilateral Arbitration Treaty available for publication and discussion. All views expressed and errors are those of the authors alone.

2 Compare OECD, Policy Brief "Small and Medium-sized Enterprises: Local Strength, Global Reach” (OECD, Paris, 2000) at 1.

3 In New Zealand, a "small” business is defined as any business with fewer than 20 employees, a "small-medium" business is defined as any business with between 20 and 49 employees, and a "medium" business is defined as a business with 50 to 99 employees: Ministry of Business, Innovation and Employment (“MBIE”), The Small Business Sector Report 2014 (Wellington, 2014) at 10, 12.

4 MBIE Small Businesses in New Zealand: How do they compare with larger firms? (Wellington, March 2013) at 1.

5 MBIE The Small Business Sector Report 2014 (Wellington, 2014) at 8. 
43 per cent of the workforce. ${ }^{6}$ Small and medium-sized enterprises are responsible for approximately 34 per cent of New Zealand's GDP. ${ }^{7}$

The relatively small size of the New Zealand market means that New Zealand businesses are subject to considerable constraints on their ability to grow. This size also means that the New Zealand economy is highly dependent on international trade. ${ }^{8}$ Expansion into international markets is therefore critical for many businesses' continued growth, and for the economy's (and ultimately the consumers') wellbeing. Despite the obvious case for expansion, only 38 per cent of SMEs currently export their products. ${ }^{9}$

One of the reasons for this limited foray into foreign markets is the risk associated with doing so. SMEs world-over lack the ability to access justice when trading relationships take a turn for the worse. ${ }^{10}$ Like individuals and marginal groups in society, ${ }^{11}$ businesses face hurdles in accessing justice. ${ }^{12}$ However, the latter is rarely examined in public discourse.

Notwithstanding this lack of attention, the issue is important. While large businesses and multinationals are generally sufficiently well-resourced to take on their contractual counterparts should the need arise, ${ }^{13}$ the same is not true for smaller operations. ${ }^{14}$

6 MBIE Small Businesses in New Zealand: How do they compare with larger firms? (Wellington, March 2013) at 1; MBIE, The Small Business Sector Report 2014 (Wellington, 2014) foreword. Not included in small businesses are self-employed traders which number over 380,000 .

7 MBIE Small Businesses in New Zealand: How do they compare with larger firms? (Wellington, March 2013) at 2. See also: MBIE, The Small Business Sector Report 2014 (Wellington, 2014) at 8.

8 Statistics New Zealand "Trading Economics" < www.tradingeconomics.com> (2014).

9 MBIE Small Businesses in New Zealand: How do they compare with larger firms? (Wellington, March 2013) at 2.

10 For example, The Bar Council of Ireland, Small Claims Arbitration system (2005) <www.lawlibrary.ie>; compare also Daniel Girsberger "Eine optimale Form der Streiterledigung fuer KMU?” (2002) <http://www.wengervieli.ch>.

11 See, for example: New Zealand Law Commission "Women and Access to Justice" (July 1996) New Zealand Law Commission </www.lawcom.govt.nz/project/women-and-accessjustice>; AC Nielsen (Report commissioned by the Ministry of Justice) "Public Perceptions of the New Zealand Court System and Processes” (1999-2006) ; Saskia Righarts and Mark Henaghan "Public Perceptions of the New Zealand Court System: An Empirical Approach to Law Reform” (2010) 12 Otago L Rev at 329; The Right Honourable Lord Woolf Access to Justice: Final Report to the Lord Chancellor on the Civil Justice System in England and Wales (HMSO, July 1996); Victorian Law Reform Commission Civil Justice Review (2008); but see also as general problem for the ordinary citizen: New Zealand Law Commission “Delivering Justice for All” (NZLC 85, March 2004) <www.justice.govt.nz>.

12 See The Bar Council of Ireland, Small Claims Arbitration system (2005) $<$ www.lawlibrary.ie>.

13 An indication for the ability is the amount big businesses do report on legal fees. For example: "Bank of America reports \$70m loss on huge legal costs" RTE News (Ireland, 15 October 2014); “McKillen faces $€ 5.5 m$ bill for Quinlan’s legal costs” The Irish Independent (online ed, Ireland, 29 March 2014); The Independent UK "UBS misses profit estimate for third quarter on legal costs” (online ed, 28 October 2014).

14 See The Bar Council of Ireland "Are you an SME with a dispute against a trader in another EU Member State?” <www.lawlibrary.ie>: "Unfortunately going to court is not an option for 
Given the importance of trade, there is a need to enable New Zealand SMEs to operate effectively in the international space.

Presently, international trade between private parties operates a default dispute resolution system of international litigation. Recent research suggests that for many SMEs international litigation is an unsatisfactory vehicle for providing access to justice. ${ }^{15}$ Unfamiliar and uncertain judicial procedure, difficulties with enforcement of judgments against foreign trading partners, and the costs associated with resolving disputes in the international space mean that SMEs that do engage in trade are potentially not able to bring effective resolution to their disputes. As a result of those potential difficulties and costs, many SMEs do not engage in trade that would be beneficial, their growth is constrained and they are unable to reach their maximum potential. The consequence of this constraint is that the SMEs, and the communities in which they operate, are worse off.

However, there may be at least a partial solution. In 2012 Gary Born proposed the creation of a default regime of cross-border dispute resolution: a Bilateral Arbitration Treaty ("BAT"). ${ }^{16}$ A BAT would fundamentally alter the dispute resolution framework in which businesses operate. It would remove the disputes that arise between international businesses in two or more states from the jurisdiction of local courts unless businesses opt out of the BAT's application, and would instead see those disputes resolved through a system akin to international arbitration. ${ }^{17}$

most businesses as it can be expensive, stressful and time-consuming, and this is even more likely to be true when different languages and differing legal systems are involved.”

15 Compare European Commission, European contract law in business-to-business transactions: Summary (2011); World Bank and the International Finance Corporation Doing Business 2012 (2012) - both studies found that international litigation poses a significant trade barrier for SMEs and businesses in general. The authors note that empirical evidence in regard to New Zealand SMEs is lacking. However, there is no indication that New Zealand SMEs have a different experience. On the contrary, if $30 \%$ of European SMEs - whose business capacity (a European SME being defined as a business with up to 249 employees) is so much stronger and therefore should be able to budget much better for legal advice - see cross-border litigation as a major barrier to cross-border trade. The Bar Council of Ireland's findings in "Are you an SME with a dispute against a trader in another EU Member State?" draw the same conclusion in regard to Ireland: "Unfortunately going to court is not an option for most businesses as it can be expensive, stressful and time-consuming, and this is even more likely to be true when different languages and differing legal systems are involved.” Ireland has a similar population size to New Zealand.

16 The draft Bilateral Arbitration Treaty is annexed to this article.

17 Gary Born, "BITS, BATS and Buts" (Kiev Arbitration Days 2012, Kiev, 15, 16 November 2012); see also Gary Born at University of Pennsylvania Law School "BITS, BATs and Buts - Reflections on International Arbitration" YouTube video $<$ http://youtu.be/ZdRjWcPQB_s >.

The authors note that the system of dispute resolution created under a BAT can be characterised as a state-devised dispute resolution mechanism that relies on and uses international arbitration concepts rather than international arbitration in the strict sense. Since the discussion and criticism of the BAT so far has been couched in terms of the BAT as constituting international arbitration, the authors have based their arguments on that characterisation for the purposes of this paper. See in regard to a discussion of the BAT as a state-devised dispute resolution mechanism: Asher Emanuel, The Constitutionality of Default Arbitration (LLM research paper, Victoria University, 2015) 
A BAT would - by directing the resolution of disputes to arbitration serve to give SMEs greater access to justice in the international space than is available under the status quo. Arbitration provides an answer to many of the issues that international litigation poses for SMEs, and this enhanced access to justice would foster international trade involving SMEs. Increased trade would result in benefits which accrue to the SMEs themselves, as well as to the community more generally through the positive contribution they make to New Zealand's (and New Zealand's trading partners') GDP.

This paper will proceed in two parts. The first outlines Born's proposal for a BAT, examines some fears the concept of the BAT may engender, and seeks to allay those concerns. The second part examines and discusses the right to access to justice for SMEs. A BAT will foster the businesses' right to effective justice by ameliorating the current issues that the existing default system of international litigation poses, especially for SMEs. However, on the other hand a BAT limits the right to access to the courts in cases of cross-border disputes. Both facets of the right to access to justice need to be balanced with each other. The paper argues that the balance lies with effective justice for businesses, especially for SMEs.

\section{ThE PROPOSAL: A BILATERAL ARBITRATION TREATY}

\section{A. Outline of the BAT}

At its core, Born's proposal is a relatively simple one. ${ }^{18}$ States would agree to substitute international litigation with international commercial arbitration as the default dispute resolution regime between commercial entities trading between those states.

Such agreement would be by way of treaty. Of course, the treaty need not be bilateral - indeed it would work best where many states were party to a single treaty, ie as a multilateral treaty. And it does not need to operate as a standalone treaty - it could quite naturally fit into a preferential trade agreement or another multilateral treaty (such as the Trans-Pacific-Partnership Agreement).

Arbitration under a BAT would be the default dispute resolution mechanism. Parties would remain free to opt out by (a) selecting some other forum (by way of a forum selection or choice of court clause), (b) prescribing an arbitration procedure that is different from the procedure mandated under the BAT, or (c) agreeing that the BAT would not apply to disputes arising between those parties (in which case the ordinary rules of private international law would apply, and the dispute would fall to be resolved by the courts).

A BAT would provide for those matters that can be subject to arbitration. It would provide for the types of transactions that would fall within its scope, namely, transactions between private enterprises located in the contracting

18 Gary Born "BITS, BATS and Buts” (Kiev Arbitration Days 2012, Kiev, 15, 16 November 2012). 
states. ${ }^{19}$ And it would carve out those subject matters over which, for reasons of public policy, states wish to retain judicial oversight. ${ }^{20}$

In addition, a BAT would prescribe those factors ordinarily found in a full arbitration agreement: the rules according to which the arbitration is to be conducted, the number of arbitrators, and the appointing mechanism. Born suggests the use of the UNCITRAL Rules of Arbitration, ${ }^{21}$ and the designation of the Permanent Court of Arbitration ("PCA") as the appointing authority. ${ }^{22}$ Those choices, he reasons, would create an environment providing maximal neutrality to international disputants.

Where a dispute was subject to the BAT, the courts in both states would decline to find jurisdiction, would stay any proceedings, and would refer the dispute to arbitration. This is in line with the current practice of national courts when faced with an arbitration agreement. ${ }^{23}$ Similarly, state courts would recognise and enforce arbitral awards rendered in the course of arbitration under the BAT. ${ }^{24}$

\section{B. The "But": Consent}

As might be expected with a proposal of this nature, the BAT presents several issues that seem to militate against its utility. Born identifies five: the apparent affront to the constitutional guarantee of access to justice, consent (or the apparent lack thereof), the mechanics of the arbitral process, the existence of regimes that already seek to address some of the problems with international litigation, and a fear of the unknown. ${ }^{25}$

The first of these - the issue of access to justice - goes to the thesis of this article and, accordingly, it is addressed separately and in greater detail in Part III. ${ }^{26}$ The third, fourth and fifth are dealt with in other sections of this article. ${ }^{27}$ It is the final one - the issues of consent - with which this section is primarily concerned.

19 See Draft BAT, art 1 "International Commercial Dispute”

20 For example: competition and employment matters.

21 Draft BAT, art 4(1)(a).

22 Draft BAT, art 4(1)(b).

23 See Article II(3) of the Convention on the Recognition and Enforcement of Arbitral Awards (New York, 1958) (“New York Convention”), and art 8(1) of the UNCITRAL Model Law on International Commercial Arbitration (1985).

24 Article III of the New York Convention; UNICITRAL Model Law on International Commercial Arbitration (1985) art 36.

25 Gary Born “BITS, BATs and BUTS” (Kiev Arbitration Days 2012, Kiev, 15, 16 November 2012).

26 See below 196.

27 For the mechanics of the process, see the outline of the BAT citing the application of the UNCITRAL rules and use of the PCA as the appointing authority above at II A. For the existence of alternative regimes see the discussion of the general issues with international litigation at III A, below. For the fear of the unknown, see generally the discussion of similar regimes at 3(b), (c) and (d) of this Part. 
Fundamentally, arbitration is a creature of consent. ${ }^{28}$ Tribunals derive their authority from the agreement of the parties. It is only through agreement that parties can seek to oust the jurisdiction of an otherwise competent court. ${ }^{29}$ However, the foundation of a BAT is that no consent is required - at least not in any explicit sense. In essence, a BAT operates by imposing international arbitration on parties. "Imposing" international arbitration on parties is prima facie contrary to the core premise and basis of (international) arbitration - the consent of the parties. The following discussion examines the role of consent under a BAT.

\section{Arbitration is a default mechanism}

Fundamental to Born's proposal is that the BAT is only a default mechanism. Parties remain free to opt out of the application of the BAT expressly or impliedly. Parties may do so by selecting some other form of dispute resolution (including institutional arbitration), or some other forum (by, for example, a choice of court clause). Equally, parties can opt out by agreeing that the provisions of the BAT do not apply; in that case any disputes will fall to be resolved by the existing default system.

In this respect, the mechanics of the BAT are consistent with the existing framework in which arbitration operates, and in which parties' autonomy is manifest.

Arbitration operates in a hierarchy with multiple tiers of sources of law or rules. Each tier fills gaps in the tier above. The parties' agreement as to procedure is supplemented by institutional rules, which are themselves supplemented by the law of the seat. Considered in this framework, the BAT respects the parties' intentions, filling gaps only where no intention has been expressed or can be implied.

In this connection, the BAT does not operate in a way that is altogether that different from arbitration law more generally, and does not mark a meaningful departure from the consensual nature of arbitration.

\section{Actual consent}

Second, in some cases there will be actual consent to arbitration. ${ }^{30}$

A BAT would contain an obligation on governments to ensure awareness of the BAT and its effect. Assuming states discharge this obligation, businesses would be aware of the default regime. In this respect, a BAT does

28 See: Andrea Steingruber Consent in International Arbitration (Oxford University Press, Oxford, 2012); Alan Redfern, Martin Hunter et al, Redfern and Hunter on International Arbitration (5th ed, Oxford University Press, Oxford, 2009) at [3-01]; Gary Born International Commercial Arbitration Vol I (Kluwer Law International, New York, 2009) at 90; Julian Lew, Loukas Mistelis \& Stefan Kröll, Comparative International Commercial Arbitration (Kluwer Law International, The Hague, 2003) at [1-11].

29 Julian Lew, Loukas Mistelis \& Stefan Kröll, Comparative International Commercial Arbitration (Kluwer Law International, The Hague, 2003) at [1-10]. See also art II(1) of the New York Convention.

30 Such a view is not universally accepted, see Luis Bermejo "Mandatory ICC Provision in Guatemala’s Arbitration Law is Declared Unconstitutional by the Constitutional Court of Guatemala” (2011) 14(5) International Arbitration Law Review. 
not operate by stealth. Once in force, well-informed parties will be aware of its operation and parties unaware of its operation will be in a better position than they would otherwise have been. Businesses could then take advice and make informed decisions regarding the appropriateness of the BAT's provisions to their transactions.

The absence of an express agreement to arbitrate once the BAT is in force should not be taken as a lack of awareness (and therefore possible lack of consent) on the part of the parties. It is understandable that where parties are satisfied with a default regime they do not express that satisfaction in an explicit way. The reasons for this are several. In the case of some agreements, unnecessary detail may be omitted for reasons of drafting economy; in other agreements it may be omitted to minimise the transaction costs associated with negotiating appropriate wording with which to express a given intention; in others still it may be because the parties simply do not consider there is a need for them to make such an expression.

\section{Constructive consent}

Third, while arbitration requires consent, there is no reason in principle why that consent must be express and by the parties themselves. Constructive consent is wholly consistent with the notion of consent in arbitration, and is already recognised in a number of areas.

\section{(a) Bilateral Investment Treaties}

Bilateral Investment Treaties (BITs), now ubiquitous, operate on a constructed notion of consent. The US Model Bilateral Investment Treaty provides that where a dispute cannot be resolved by consultation or negotiation, the disputing party may submit the dispute to arbitration. ${ }^{31}$

Though a BIT does not create an arbitration agreement between the state and the investor (at least not in the traditional sense of an agreement), art 25 does contain an express (albeit conditional) statement of consent to arbitration on the part of the contracting states. ${ }^{32}$ This form of consent on the part of a state has long been accepted in the context of BITs. ${ }^{33}$

(b) Court-ordered arbitration

Court-ordered arbitration is not available in New Zealand (and indeed was rejected from inclusion in the Arbitration Act 1996), ${ }^{34}$ but is common in a

31 US Model Bilateral Arbitration Treaty (2012), art 24(1).

32 "Each Party consents to the submission of a claim to arbitration under this Section in accordance with this Treaty."

33 David A R Williams and Amokura Kawharu Williams \& Kawharu on Arbitration (LexisNexis, Wellington, 2011) at 15. Written consent is said to exist in the form of the treaty: Campbell McLachlan, Laurence Shore and Matthew Weiniger International Investment Arbitration: Substantive Principles (Oxford University Press, Oxford, 2008) at [3.28] and [4.60]. See also Jan Paulsson The Idea of Arbitration (Oxford University Press, Oxford, 2013) at 53.

34 See: David A R Williams and Amokura Kawharu Williams \& Kawharu on Arbitration (LexisNexis, Wellington, 2011) at 16. See also New Zealand Law Commission Arbitration (NZLC R20, 1991) at [109]-[110]. 
number of other jurisdictions. ${ }^{35}$ In these jurisdictions there is no agreement to arbitration at all. Despite this lack of consent and agreement, there is no doubt that the procedure is arbitration. Nor is there doubt that the awards rendered are arbitral awards as capable of enforcement in the same manner as awards rendered by a tribunal established by agreement.

(c) Legislatively prescribed arbitration

Legislatively prescribed arbitration (or other forms of binding dispute resolution) is also not uncommon.

Prior to 1987, New Zealand's various industrial relations enactments provided for a system of arbitration for selected employment and industrial disputes. ${ }^{36}$ A similar system to that of pre-1987 New Zealand continues to exist in Australia. There, the Fair Work Commission may have powers of compulsory arbitration. ${ }^{37}$ Further, in Queensland arbitration is mandatory under the Gas Pipeline Access Act 1998 (Qld). ${ }^{38}$

In all of these circumstances there is no consent or agreement in the traditional sense that has come to be expected in arbitration. Rather, consent to arbitration or some other non-court resolution is inferred from participation in an area or sector where that alternative dispute resolution system is compelled.

(d) Similar regimes

The idea behind the BAT is not wholly novel. In 1972 the former Council for Mutual Economic Assistance ("CMEA") states concluded the Convention on the Settlement by Arbitration of Civil Law Disputes Resulting from Relations of Economic and Scientific-Technical Cooperation. The Moscow Convention, as it is known, provided for compulsory arbitration between economic entities in the CMEA states. ${ }^{39}$ The Convention went further than simply compelling arbitration. The Convention forced the parties' disputes into a (or, in the case of most states, the) court of arbitration in the state of the respondent unless the parties agreed on a mutually acceptable third state. ${ }^{40}$

Similarly, until 1994 the China International Economic and Trade Arbitration Commission (CIETAC) and China Maritime Arbitration

35 For example: California, Code Civ Proc §1141.10; Supreme Court Act 1970 (NSW) s $76 B$.

36 See: Industrial Conciliation and Arbitration Act 1894, Industrial Relations Act 1973, and Industrial Relations Amendment Act 1977.

37 Fair Work Act 2009 (Cth) s 737; Fair Work Regulations 2009 (Cth) r 6.01. The Regulations contain a model approach to dispute settlement which gives Fair Work Australia powers of compulsory arbitration. Parties are not required to adopt the model approach, but in practice limiting the role of Fair Work Australia is difficult. In addition, in 2010 the Government introduced Fair Work Principles. The principles required certain suppliers to the Australian Government to include arbitration provisions in their enterprise agreements, and to the extent possible require the same of their subcontractors. The principles were revoked from July 2014.

38 Gas Pipeline Access Act 1998, s 15(1).

39 Convention on the Settlement by Arbitration of Civil Law Disputes Resulting from Relations of Economic and Scientific-Technical Cooperation (The Moscow Convention) 1972, art 1(1).

40 Moscow Convention 1972, art 2(1). 
Commission (CMAC) had exclusive jurisdiction over certain kinds of international disputes involving Chinese parties. ${ }^{41}$

While the existence of these earlier regimes does not, in itself, provide a complete answer to the issues with consent, it does serve to illustrate that the issues with consent have not previously been insurmountable.

\section{The type of consent}

If asked how disputes should be resolved, most commercial parties would be unlikely to answer "by litigation" or "by arbitration". As might be expected, most businesses are outcome-focused and are not troubled by the specific details of procedure (except to the extent that they impact on the outcome). Instead, a business is likely to respond that it wants disputes resolved quickly, neutrally, expertly, cheaply and with a result that is enforceable. ${ }^{42}$ A commercial party that has not put its mind towards cross-border dispute resolution when entering its cross-border trading relationship will focus, when the need arises, on the practicalities of effective dispute resolution. ${ }^{43}$ Because the BAT presents a default position that satisfies these expectations, even if a deliberate and reflected consent to arbitration is lacking, implied consent to arbitration under the BAT can be inferred.

\section{Summary}

For the reasons set out in this Part, consent to arbitration under a BAT is not lacking. But even if there is a lack of consent in the formal sense, when a broader view is taken of the notion of consent it is arguable that even where parties have not considered arbitration they have consented to a dispute resolution process that satisfies their expectations when it comes to resolving disputes. And arbitration under a BAT does just that.

\section{Concluding Observations}

A BAT between two or more state parties will reduce some of the ills of cross-border litigation that have been identified in recent surveys conducted by the European Commission and the World Bank. ${ }^{44}$ A BAT would allow the states to put in operation the best features of international arbitration for their businesses.

41 See Kun Fan “Arbitration in China: Practice, Legal Obstacles and Reforms” (2008) 19(8) ICC Bull. In 1994 China enacted the Arbitration Law of the People’s Republic of China, which no longer requires resolution of disputes by CMAC and CIETAC.

42 Queen Mary and PricewaterhouseCoopers "International arbitration: Corporate attitudes and practices" (2006) <www.pwc.be>; School of International Arbitration, Queen Mary, University of London \& PricewaterhouseCoopers "International Arbitration: Corporate attitudes and practices" (2008) <www.pwc.co.uk/>; PricewaterhouseCoopers \& School of International Arbitration, Queen Mary, University of London "Corporate choices in International Arbitration Industry perspectives” (2013) <www.pwc.com>.

43 Compare Meike Guskow “Jeden Stein umdrehen - Im Blickpunkt: Konfliktmanagement und Streitbeilegung in einem mittelstaendischen Unternehmen” (2013) <http://disputeresolutionmagazine.de/jeden-stein-umdrehen/>.

44 European Commission European contract law in business-to-business transactions: Summary (2011); World Bank and the International Finance Corporation Doing Business 2012 (2012). 
The preceding examination of the BAT discussed a BAT's place in dispute resolution. Though particular attention has been paid to the "quality" of the party's consent to the BAT, the discussion was necessarily brief and further consideration should be given to this point.

Access to justice or due process has been identified as a significant "But" relating to the implementation of a BAT. ${ }^{45}$ Principally this "But" is a related function of the parties' consent. The "But" presupposes that the parties' consent to arbitration under the BAT can either be insufficient or cannot be ascertained at all. The parties, it could be argued, are coerced into a private dispute resolution mechanism which the state constitutionally has the duty to provide. ${ }^{46}$ The following section will address the way in which a BAT would operate within New Zealand's human rights framework.

\section{ACCESS TO JUSTICE}

Access to justice on the international plane encompasses two aspects: Access to a court (or tribunal), and the right to effective justice. ${ }^{47}$ The BAT provides a case study of the way in which those two facets of the right of access to justice can be antagonistic to each other.

In New Zealand, access to justice is enshrined in the natural justice guarantee of section 27 of the New Zealand Bill of Rights Act 1990 ("BORA"). Section 27 of BORA relevantly provides:

27 Right to justice

(1) Every person has the right to the observance of the principles of natural justice by any tribunal or other public authority which has the power to make a determination in respect of that person's rights, obligations, or interests protected or recognised by law.

(2) Every person whose rights, obligations, or interests protected or recognised by law have been affected by a determination of any tribunal or other public authority has the right to apply, in accordance with law, for judicial review of that determination.

The s 27 of BORA protection focuses on a literal interpretation of the right of access to the courts. ${ }^{48}$ While the concept of "the principles of natural justice" has not been the subject of sustained judicial analysis in New Zealand, ${ }^{49}$ the

45 Gary Born, “BITS, BATS and Buts” (Kiev Arbitration Days 2012, Kiev, 15, 16 November 2012).

46 Gary Born, "BITS, BATS and Buts” (Kiev Arbitration Days 2012, Kiev, 15, 16 November 2012).

47 See in regard to both aspects of the European Court of Human Rights, "Guide on Article 6" (Council of Europe/European Court of Human Rights, 2013) <www.echr.coe.int>; art 47 Charter of Fundamental Rights, art 26 International Covenant on Civil and Political Rights; compare in regard to the latter, for example, Susan Moloney "A New Approach To Civil Litigation? The Implementation Of the 'Woolf Reforms' and Judicial Case Management” (2001) JSIJ 98.

48 See A Butler and P Butler The New Zealand Bill of Rights Act: A Commentary (2nd ed, LexisNexis, Wellington, 2015) Ch 25 (forthcoming).

49 A Butler and P Butler The New Zealand Bill of Rights Act: A Commentary (2nd ed, LexisNexis, Wellington, 2015) 25.2.4 (forthcoming). 
Court of Appeal has confirmed that s 27 is not restricted to a specific class of natural justice rights, nor is it restricted by art 14(1) of the International Covenant on Civil and Political Rights. ${ }^{50}$ The proper approach to the interpretation and application of s 27 is a generous interpretation of the right for the purposes of the initial scope under Part II of BORA, ${ }^{51}$ with limits on the right to be determined by reference to s 5 of BORA. ${ }^{52}$ Therefore, s 27 enshrines the full gamut of already existing rights concerning natural justice.

The jurisprudence also suggests that s 27 creates a right to effective justice. The fixing of (substantial) costs without both parties having an opportunity to present submissions, ${ }^{53}$ and the dismissal of an appeal under ex parte procedures due to denial of legal aid ${ }^{54}$ have both been held to infringe s 27 . Comparative jurisprudence, in particular from the European Court of Human Rights ("ECtHR"), strengthens the argument that effective justice is a necessary part of access to justice or natural justice. ${ }^{55}$ In Bellet $v$ France the ECtHR held that for the right of access to justice to be effective, an individual must "have a clear, practical opportunity to challenge an act that is an interference with his rights". ${ }^{56}$

Section A of this Part examines some of the issues SMEs face when it comes to international trade and dispute resolution, and which hinder SMEs' effective access to justice in cross-border disputes. In each case, the ways in which a default regime of arbitration under the BAT can solve these problems are examined. Section B then addresses the "but" relating to access to justice flagged in Part II, namely a SME’s right to access to a court or tribunal.

\section{A. Barriers Posed by International Litigation and the Solutions the BAT Provides}

A recent survey conducted by the Ministry of Business Innovation and Employment reveals that the primary barriers SMEs face to exporting or to expansion into offshore markets stem from a lack of familiarity with operating

50 Combined Beneficiaries Union Inc v Auckland City COGS Committee [2009] 2 NZLR 56 (CA) [21].

51 See to this effect Unitec Institute of Technology $v$ Attorney-General HC Wellington CIV 2005-485-89, 7 July 2005 at [159]-[160] per Miller J.

52 See Petra Butler "Bill of Rights" in Mary-Rose Russell and Matthew Barber (eds) The Supreme Court of New Zealand 2004-2013 (Thomson Reuters, Wellington, 2015) (forthcoming); A Butler and P Butler The New Zealand Bill of Rights Act: A Commentary (2nd ed, LexisNexis, Wellington, 2015) Ch 6 (forthcoming).

53 Matthews $v$ Marlborough District Council [2000] NZRMA 451 (HC); see also in regard to art 6 ECHR Kreuz v Poland (no 1) (28249/95) 19 June 2001 at [60]-[67]; PolPure v Poland (39199/98) 30 November 2005 at [65]-[66]; Weissman and others $v$ Romania (63945/00) 24 May 2006 at [37], [42].

54 Attorney-General v Chapman [2011] NZSC 110.

55 See, for example, Kreuz $v$ Poland (no 1) (28249/95) 19 June 2001 at [60]-[67]; Weissman and others $v$ Romania (63945/00) 24 May 2006 at [37].

56 (23805/94) 4 December 1995 at [36]; see also in regard to a summary of the ECtHR jurisprudence European Court of Human Rights "Guide on Article 6" (Council of Europe/European Court of Human Rights, 2013) < www.echr.coe.int>. 
in a foreign country. ${ }^{57}$ Though local empirical research is lacking, ${ }^{58}$ more directed research into specific issues affecting SMEs in this area has been conducted overseas.

The European Commission, the World Bank, and the International Finance Cooperation have conducted research into the kind of unfamiliarity that is prohibitive in regard to cross-border trade of SMEs. The World Bank and the International Finance Corporation in their 2012 co-published study, Doing Business 2012, reported that efficiency and transparency in dispute resolution were pivotal in encouraging cross-border trade. ${ }^{59}$ In a study into intra-EU trade by SMEs, the European Commission found that one third of respondents felt that difficulties relating to the resolution of cross-border conflicts stifled their cross-border trade. ${ }^{60}$ What these statistics show is that the majority of businesses feel a barrier to overseas trade which at least partly originates from uncertainties relating to dispute resolution, ${ }^{61}$ and that SMEs are not confident that they will be provided with effective justice in relation to cross-border disputes.

SMEs are right to fear international dispute resolution. The costs of resolving domestic disputes by way of litigation in the High Court are high. While New Zealand data is not available, anecdotally estimates put the starting price for even a simple domestic trial at upward of $\$ 100,000$. In the international space this is even greater. International litigation has a layer of complexity not seen in domestic disputes. ${ }^{62}$ Such complexity gives rise to substantially higher costs.

In the mind of the public, businesses have in-house legal counsel and keep one of the leading law firms on retainer. In reality, only a small minority of businesses have in-house counsel, and fewer still have enough capital available to retain legal advice from the country's most experienced lawyers. So while

57 MBIE The Small Business Sector Report 2014 (Wellington, 2014) at 8.

58 Initial discussion by the authors with industry representatives and businesses indicate that cross-border litigation is, for the reasons discussed below, avoided and the BAT would be welcomed.

59 World Bank and the International Finance Corporation Doing Business 2012 (2012).

60 European Commission European contract law in business-to-business transactions: Summary (2011); Stefan Vogenauer and Stephen Weatherill “The European Community's Competence to Pursue the Harmonisation of Contract Law - an Empirical Contribution to the Debate” in Stefan Vogenauer and Stephen Weatherill (eds) The Harmonisation of European Contract Law: Implications for European Private Laws, Businesses and Legal Practice (Hart, Oxford, 2006) at 105, 128.

61 In New Zealand the data collected does not include any specific data in regard to (cross-border) dispute resolution. Compare, in regard to the US, William Fiske "Should Small and Medium-Size American Businesses "Going Global” Use International Commercial Abitration?” (2005) 18 Transnat'l Law 455.

62 Compare Thomas Carbonneau Cases and Materials on International Litigation and Arbitration (Thomson/West, St Paul, 2005) Ch 1 §2; Michael McIlwraith, Elpidio Villarreal and Amy Crafts "Finishing Before you Start: International Mediation” in Barton Legum (ed) International Litigation Strategies and Practice (American Bar Association, Chicago, 2005) at 41; Carolyn Lamm and Eckhard Hellbeck "When to Arbitrate Rather than Litigate" in Barton Legum (ed) International Litigation Strategies and Practice (American Bar Association, Chicago, 2005) at 157. 
large, well-resourced corporations are able to effectively pursue claims in international courts, ${ }^{63}$ these businesses account for only a small fraction of those operating in New Zealand. In the event of a dispute many SMEs will have exhausted their resources before the dispute advances beyond the procedural stages.

International litigation has numerous issues that have a practical, significant and adverse effect on international trade. Many of these characteristics are not specific to international litigation but are symptomatic of dispute resolution (whether international or domestic) more generally. But there are several issues that are particular to international litigation, and which we submit can be remedied (at least in part) through a BAT. It is these issues that this section seeks to identify.

\section{Duplication and multiplicity of proceedings}

International litigation presents a substantial risk of duplicate or multiple proceedings.

With limited exceptions for certain economic areas, ${ }^{64}$ international litigation proceedings are not subject to a single, comprehensive body of law that determines the state whose courts are responsible for hearing a given dispute. Rather, each state has its own procedures and laws which govern where and in what circumstances parties can commence and suspend proceedings. As a result disputing parties frequently commence proceedings in multiple jurisdictions: the place of contracting, the place of performance, their own jurisdiction and the jurisdiction of the counterparty.

Many of these proceedings will fall away as the case continues toward resolution, but it is possible that some continue to a full trial. Argument by the parties in an effort to suspend one set of proceedings will itself be costly and complex. $^{65}$

The net effect is twofold: effective resolution of disputes in the international space requires parties to be familiar with a large set of procedural rules, and be sufficiently well resourced to entertain the same complaint in multiple jurisdictions.

Even after a judgment is rendered the problem continues. First, where a party against whom a judgment has been rendered does not voluntarily comply

63 An indication for the ability is the amount big businesses do report on legal fees. For example: "Bank of America reports $\$ 70 \mathrm{~m}$ loss on huge legal costs" RTE News (Ireland, 15 October 2014); “McKillen faces $€ 5.5 \mathrm{~m}$ bill for Quinlan’s legal costs” The Irish Independent (online ed, Ireland, 29 March 2014); “UBS misses profit estimate for third quarter on legal costs” The Independent (online ed, UK, 28 October 2014).

64 See for example the Trans-Tasman Proceedings regime in Australia and New Zealand and Council Regulation (EC) No 44/2001 of 22 December 2000 on jurisdiction and the recognition and enforcement of judgments in civil and commercial matters in the European Union (the Brussels I Regulation).

65 See James George “Parallel Litigation” (1999) 51 Baylor L Rev 769 773-774; José Astigarraga and Scott Burr “Antisuit Injunctions, Anti-Antisuit Injunctions, and Other Worldly Wonders” in Barton Legum (ed) International Litigation Strategies and Practice (American Bar Association, Chicago, 2005) at 89 et seq; James Fawcett and Janeen Carruthers Cheshire, North \& Fawcett: Private International Law (14th ed, Oxford University Press, Oxford, 2008) 455 et seq. 
with that judgment, proceedings will be required to compel compliance. Because of the absence of international treaties and standards on the recognition and enforcement of foreign judgments, enforcement is particularly complex and full of uncertainty. ${ }^{66}$ Each state has its own criteria that must be met for a judgment to be enforced, and not all states will recognise judgments from the courts of all other states. Secondly, where multiple proceedings have resulted in judgments that are inconsistent, enforcement may not be possible at all.

Consequently, parties who do proceed to international litigation may never actually obtain the very justice that they seek.

One of the key benefits of international arbitration generally is that it minimises the risk of parallel or multiplicitous litigation. The New York Convention on the Recognition and Enforcement of Foreign Arbitral Awards 1958 ("the New York Convention") obliges state courts seized of a dispute to refer the dispute to arbitration in the face of an agreement to arbitrate. ${ }^{67}$ This position is also reflected in the UNCITRAL Model Law on International Commercial Arbitration. ${ }^{68}$ Though unlikely to ever be at issue under the BAT, ${ }^{69}$ courts have generally strained to give effect to this obligation even in the face of manifest pathology in an arbitration agreement. ${ }^{70}$ They have used their discretionary case management powers to stay proceedings even where the dispute may not strictly be within the ambit of the submission to arbitration. ${ }^{71}$

66 Thomas Carbonneau Cases and Materials on International Litigation and Arbitration (Thomson/West, St Paul, 2005), Ch 1. See also Edward Davis Jr and Annette Escobar "A Practitioners Guide to Enforcement of Foreign Country Money Judgments in the United States" in Barton Legum (ed) International Litigation Strategies and Practice (American Bar Association, Chicago, 2005) at 131; James Fawcett and Janeen Carruthers Cheshire, North \& Fawcett: Private International Law (14th ed, Oxford University Press, Oxford, 2008) at 514; Carolyn Lamm and Eckhard Hellbeck "When to Arbitrate Rather than Litigate" in Barton Legum (ed) International Litigation Strategies and Practice (American Bar Association, Chicago, 2005) at 157-158.

67 The New York Convention on the Recognition and Enforcement of Foreign Arbitral Awards (1958), art II(3).

68 UNCITRAL Model Law, art 8(1). A position mirrored in the New Zealand Arbitration Act 1996, sch 2, art 8(1).

69 As it contains provision similar to that of art 8(1) of the UNCITRAL Model Law, see Draft BAT art 3.

70 See for example HKL Group Ltd v Rizq International Holdings Pte Ltd [2013] SGHCR 5 where the Singapore High Court upheld a pathological arbitration clause, provided the parties were able to secure the agreement of an arbitration institution in Singapore (per the reference in the clause) to conduct the arbitration. See also Insigma Technology Co Ltd v Alstom Technology Limited [2008] SGHC 134, [2009] SGCA 24.

71 See for example, Danone Asia Pacific Holdings Pte Ltd v Fonterra Co-Operative Group Ltd [2014] NZHC 1681 (17 July 2014) where the New Zealand High Court ordered a stay of proceedings pending arbitration in Singapore even where there was no identity of the parties between the court and arbitral proceedings, and upheld on appeal - Danone Asia Pacific Holdings Pte Ltd v Fonterra Co-Operative Group Ltd [2014] NZCA 536; Reichhold Norway ASA \& Anor v Goldman Sachs International (A Firm) [2000] 1 WLR 173; Braes of Doune Wind Farm v Alfred McAlpine [2008] EWHC 426. 
Arbitration also cures the problems parties face when it comes to enforcement, with the New York Convention providing for the recognition and enforcement of arbitral awards. ${ }^{72}$ While the grounds on which an enforcing court may review a foreign judgment vary between states, the New York Convention provides an extremely limited set of defences to the enforcement of an arbitral award. ${ }^{73}$ Such grounds include incapacity of one of the parties, a failure of due process (or some other flaw in proceedings), the award having been set aside in the country in which it was rendered, or enforcement being contrary to the public policy of the state in which enforcement is sought. What is particularly noteworthy is that the Convention does not allow for a review of the merits of the award when enforcement is sought.

Judicial review is similarly constrained. Ordinarily judicial review is only available in relation to issues of procedural impropriety and public policy. ${ }^{74}$ Where judicial review of the substance of a decision is available, ${ }^{75}$ it is typically highly deferential to the arbitrator's decision. ${ }^{76}$

To minimise the risk of disputes, the BAT would deem awards rendered by tribunals established under the BAT to be arbitral awards for the purposes of the New York Convention. ${ }^{77}$ Such a provision is arguably necessary because of the lack of consent to arbitration, at least in the traditional sense of a positive agreement, under the BAT. ${ }^{78}$ This lack of consent, as noted earlier, means that while the dispute resolution system provided for by the BAT resembles arbitration, many states may consider that it is not arbitration of the type contemplated by the New York Convention. Ultimately a state's acceptance of the system will turn on how that state conceives of arbitration. If a state views arbitration as Gaillard posits, as transnational legal order, then it may not support policies that push the bounds of existing consensus. ${ }^{79}$ Where this is the case, arbitration conducted under the BAT (and,

72 The ECtHR held that effective enforcement was within the ambit of art 6 ECHR (Burdov $v$ Russia Application no 59498/00 (4 September 2005) [35]-[37]).

73 See New York Convention, art V. In particular, there can be no review of an award on the merits.

74 Gary Born International Commercial Arbitration Vol I (Kluwer Law International, New York, 2009) at 81.

75 Such as in China, (art 58(4) and (5), 63, 217(4) and (5), Chinese Arbitration Law) England (English Arbitration Act 1996, s 69), Australia and New Zealand (by agreement of the parties at the time the arbitration agreement is concluded, s 34(1) Commercial Arbitration Act and art 5, sch 2, Arbitration Act 1996 (respectively)), arguably in the United States (under the manifest disregard of law standard of review, but see Hall Street Associates LLC v Mattel Inc 128 S Ct 1396 (US S Ct 2008)), and several Arab states, among others.

76 Gary Born International Commercial Arbitration Vol I (Kluwer Law International, New York, 2009) Vol II, 2638 et seq.

77 Such a provision is arguably necessary because of the lack of consent to arbitration, at least in the traditional sense of a positive agreement, under the treaty. We discuss this issue in detail below.

78 This point is discussed in greater detail below III B and above II B.

79 See generally, Emmanuel Gaillard Legal Theory of International Arbitration (Martinus Nijhoff Publishers, The Netherlands, 2010) at 45 et seq. 
consequently the awards rendered under it), would not receive the protection that the state affords traditional arbitration.

While this deeming provision only operates vis-à-vis the states party to a given BAT, as BATs become more common there is a reciprocity-driven incentive to recognise and enforce awards rendered under a substantially similar treaty even where the enforcing state is not a party to the treaty under which the award was rendered. Of course, states that are not a party (even to any similar treaty) could still elect to enforce the award if they considered that an award rendered under the Treaty was an arbitral award in the sense of the New York Convention. ${ }^{80}$

Application of the New York Convention is also near ubiquitous. There are currently 154 states party to the Convention ${ }^{81}$ meaning that parties have the ability to enforce nearly worldwide. By comparison, there is no single, comprehensive international regime for the enforcement of judgments. Such mechanisms do exist, but they are often for certain kinds of judgment only, and not universally applicable. ${ }^{82}$

The Convention therefore provides two key benefits over international litigation. First, subject to any express review obligations provided for in the parties' agreement, an arbitral award becomes final and binding on the parties when it is rendered. This avoids protracted appellate litigation (and the associated costs) and reduces the length of enforcement proceedings (and the associated costs). Secondly, awards can be enforced in virtually any country, irrespective of the relationship between the country in which enforcement is sought, the residence of the parties, and the seat of the arbitration. In this respect the Convention offers an identifiable benefit: enforcement of arbitral awards is typically very effective in practice. Research suggests that slightly more than half of arbitral awards are enforced within one year of being rendered, and the recovery of the value of the award is around 75 per cent. ${ }^{83}$

\section{Cost}

One of the most substantial issues in the quest for justice is cost. The Woolf Report into access to justice in the civil space in the United Kingdom (and from which subsequent reform leading to the 1999 civil procedure rules was born) identified, among other things, a need to make access to justice cheaper. ${ }^{84}$ This sentiment was echoed in the 2002 Final Report on Civil Justice

80 See discussion in regard to consent above II B.

81 United Nations Commission on International Trade Law < www.uncitral.org>.

82 New Zealand, for example, has a regime comprised of the Trans-Tasman Proceedings Act 2010, the Judicature Act 1908, the Reciprocal Enforcement of Judgments Act 1934, and the common law (depending on the nationality of the judgment). The European Free Trade Association has the Brussels Regulation No 44/2001 (22 December 2000) and the Lugano Convention (16 September 1988).

83 School of International Arbitration, Queen Mary, University of London \& PricewaterhouseCoopers "International Arbitration: Corporate attitudes and practices" $<$ www.pwc.co.uk> at 2 - executive summary.

84 The Right Honourable Lord Woolf Access to Justice: Final Report to the Lord Chancellor on the Civil Justice System in England and Wales (HMSO, July 1996); see also Hazel Genn 
Reform on the Hong Kong civil procedure system. ${ }^{85}$ Both reports concerned costs in regard to domestic litigation. Cross-border litigation will generally incur additional costs due to the layering of legal advice and additional administrative costs like translations.

The resolution of any dispute - international or otherwise - through an adversarial forum is invariably costly. The nature of adversarial dispute resolution is that it is destructive. However, the costs associated with international litigation mean the problem is particularly acute, and, consequently, justice is relatively harder to access.

The primary reason for the cost of international litigation being over and above that of international arbitration is because of the duplication of proceedings (addressed above at 199). In addition, there are two further factors which add to the cost of international litigation. First, there is a greater need to engage multiple sets of counsel, and, second, the counsel required to assist parties to resolve international disputes where there is uncertainty as to procedure and substance are particularly expert (and, consequently, expensive). ${ }^{86}$ We address each in turn.

(a) "Layering” of counsel

In virtually all cases of international litigation counsel will need to be layered. This stems in large part from the duplication of proceedings.

Almost all states have a regulated legal profession. Counsel qualified in one state can usually not appear in the courts of another state without local registration. The consequence is that where a dispute touches several nations it will be necessary to layer counsel.

To take an example, consider a dispute arising between a New Zealand enterprise and a counterparty located in California. Once the dispute - a failure of the Californian party to deliver goods to a plant in Singapore as required arises, each party will likely consult counsel local to them. If the agreement is governed by the laws of England then both parties will likely consult counsel skilled in that law. In the event that a dispute eventually proceeds to trial - say in Singapore (as the place of performance) - both parties will need to engage a third set of counsel (who have rights of audience in Singaporean courts). And where proceedings are also commenced in California and New Zealand, counsel will also need to be engaged in each of those jurisdictions.

"What is Civil Justice For? Reform, ADR, and Access to Justice" (2012) 24 Yale J.L \& Human at 18 .

85 Final Report Chief Justice's Working Party on Civil Justice Reform Hong Kong $\leq$ www.legco.gov.hk $>$ (March 2004).

86 In contrast Imran Benson in "In search of justice” (2012) 162 NLJ argues that especially costs in arbitration are prohibitive and in fact hinder access to justice. See also El Nasharty $v$ J Sainsbury [2007] EWHC 2618 (Comm) where the Court held that the financial situation of a party had no influence on the arbitration and that the impecuniosity of a party in arbitration was not an infringement of art 6 ECHR. See also Jaroslav Kudrna "Arbitration and Right of Access to Justice: Tips for a successful Marriage” (2013) 45(1) N.Y.U. J. Int'l L. \& Pol.. State parties to a BAT could of course agree on set arbitrator's fees and general curbed expenses- compare The Bar Council of Ireland "Are you an SME with a dispute against a trader in another EU Member State?” <www.lawlibrary.ie>. 
International disputes, no matter how they are resolved, will likely see each party engage multiple sets of counsel. However, the constraints on which counsel may be used in international litigation mean that the problem is far more acute in international litigation than it is in international arbitration. Whereas appearance in front of a court is generally restricted to counsel who hold a qualification of the court's jurisdiction, appearance in front of an international arbitral tribunal is not associated with any particular jurisdiction. Therefore, counsel, no matter where they are entitled to practice, can appear before a tribunal. This significantly reduces the need for the layering of counsel.

Of course, there may be some exceptions. If a party attempts to commence litigation proceedings, local counsel will be required to appear before the court seeking a stay of those proceedings. Such an application - especially in the context of a BAT - would be relatively straightforward and could be done at minimal cost. Parties may need to engage counsel to assist with enforcement of an award, but only where the party against whom the award was rendered does not voluntarily comply. Even then, the limited grounds of review mean that most enforcement proceedings are relatively straightforward and come at minimal cost relative to foreign judgments.

(b) Specialised advice

The third reason international litigation is particularly costly relates to the nature of the advice required in the area. While all areas of law have some degree of specialism, international litigation necessitates an understanding of an area highly specialised and not widely understood: private international law. ${ }^{87}$ Such legal expertise is costly, and in many cases will be prohibitively expensive for SMEs to obtain.

For many SMEs, the price of international dispute resolution will simply be too great to be accessible. Not willing to take the risk of encountering such costs, many SMEs shy away from international trade in which they may otherwise have been willing to engage. ${ }^{88}$

Where the law governing the merits is foreign to one of the parties (as it is likely to be), that party will need to engage counsel familiar with that law. Though typically counsel will be practitioners, there is no need for them to be

87 See, in relation to the "shortcomings" in legal education in the area, William van Caenegem and Mary Hiscock The Internationalisation of Legal Education: The Future Practice of Law (Edward Elgar, Northhampton, 2014); Stacey Steele and Kathryn Taylor (eds) Legal Education in Asia: Globalisation, Change and Contexts (Routeledge, Arlington, 2009) in particular see Jeff Waincymer "Internationalisation of Legal Education: Putting the "why" before the "how"” in Stacey Steele and Kathryn Taylor (eds) Legal Education in Asia: Globalisation, Change and Contexts (Routeledge, Arlington, 2009) at 68.

88 See in regard to the prohibitive nature of inaccessible cross-border litigation: European Commission, European contract law in business-to-business transactions: Summary (2011); World Bank and the International Finance Corporation Doing Business 2012 (2012); Stefan Vogenauer and Stephen Weatherill “The European Community's Competence to Pursue the Harmonisation of Contract Law - an Empirical Contribution to the Debate" in Stefan Vogenauer and Stephen Weatherill (eds) The Harmonisation of European Contract Law: Implications for European Private Laws, Buisenesses and Legal Practice (Hart, Oxford, 2006) 105. See also n 14. 
in active practice; academics versed in the area can be engaged, and so the pool of possible options for representation expands.

\section{Uncertainty and complexity}

The third major issue with international litigation is a consequence of its nature. Because there is no global standardisation of procedure, substantial uncertainty surrounds issues of procedure, applicable law and multiple proceedings (and the consequence of those proceedings).

Few things are guaranteed in international litigation, but issues relating to legal procedure in the relevant jurisdictions will arise almost always, and issues relating to jurisdiction, forum non conveniens, and lis pendens frequently arise. ${ }^{89}$

As a result, a New Zealand-based SME (or rather, its counsel) is required to understand not only the relevant New Zealand civil procedure rules in regard to the cross-border litigation, ${ }^{90}$ but also the civil procedure and/or substantive law of another country with which the SME is not acquainted. The costly alternative is, as discussed above, to engage local counsel who has the requisite familiarity with those laws.

This creates a number of barriers. First, without knowledge of their prospective trading partners' laws, many parties will be unable to answer basic questions such as "in the event of a dispute, how do I commence proceedings?”, or "can I sue in state X?”. This fundamental lack of understanding dissuades parties that may otherwise be willing to engage in international trade from doing so.

Arbitration does not cure these problems entirely. However, by removing the risk of multiplicitous proceedings, setting out the procedure for commencing proceedings in an accessible way, and prescribing a neutral procedure for the conduct of proceedings the BAT offers a partial solution.

Even where parties are not acquainted with the specific details of the BAT and its procedure, they may be more willing to engage in trade where they know that an international treaty will govern their dispute (rather than an unascertained or unfamiliar law).

\section{Distrust in outcome}

The fourth problem is one of perception. The possibility that litigation might take place in the country of the trading partner and the SME's lack of familiarity with that jurisdiction means that they are distrustful of the process and the outcome of proceedings. And while distrust in foreign courts is not necessarily warranted in all cases, in some states the lack of an independent or impartial judiciary or corruption of the court system do give cause for concern. ${ }^{91}$

89 Gary Born International Commercial Arbitration Vol I (Kluwer Law International, New York, 2009) 65-67.

90 See, for example, Subparts 3 and 4 of Part 6 of the High Court Rules.

91 Queen Mary and PricewaterhouseCoopers “International arbitration: Corporate attitudes and practices" (2006) <www.pwc.be> 1.2. 
The consequence is that even where parties come out of proceedings with an enforceable judgment, they do not feel that justice has been served. For those parties already engaged in international trade, they may scale back operations where they have suffered an adverse result. And for those parties that are not already engaged in trade, the perception of unfairness may be enough to prevent them entertaining the thought.

Research suggests that these three concerns are not simply academic: the 2006 Queen Mary survey reported that of those companies that do engage in international trade, the vast majority - nearly 90 per cent - seek to avoid international litigation. Principally, parties put this desire down to the costs associated with international litigation, discomfort with litigating before a foreign court under foreign law, a lack of familiarity with procedure, and the difficulties associated with enforcement of judgments. ${ }^{92}$

One of the primary issues parties have with international litigation is the apparent lack of neutrality they face when resolving their dispute. However fair the court system of a counterparty's home jurisdiction may be, foreign parties before those courts will often feel a sense of distrust in any adverse result.

The BAT solves this problem. While courts are inextricably bound to a particular state, international arbitration allows disputes to be resolved by a tribunal composed of independent third parties, ${ }^{93}$ and which does not owe its allegiance to any particular state. ${ }^{94}$

This neutrality extends beyond the decision-maker to the procedure itself. By using a set of rules that are divorced from the civil procedure of all states such as the UNCITRAL Rules of Arbitration - the procedure becomes maximally neutral. ${ }^{95}$

In this respect, the arbitration provides disputing parties what they ultimately desire. It provides a neutral forum in which they can (fairly) present their case for decision by an objective decision-maker. ${ }^{96}$

\section{The need for a BAT}

The preceding analysis shows that the BAT can reduce the issues of cross-border litigation which prevent clear and practical access to justice for

92 Queen Mary and PricewaterhouseCoopers "International arbitration: Corporate attitudes and practices" (2006) <www.pwc.be> 1.2.

93 BAT, art 4(1)(c) which as default confers the power to select the arbitrator(s) to the neutral Permanent Court of Arbitration. See in regard to the choice of arbitrators generally: UNCITRAL Rules, art 7; compare the reform of the Belgian Judicial Code which expressly acknowledges the importance of neutrality (Emmanuel Gaillard and John Savage (eds) Gaillard Goldman on International Commercial Arbitration (Kluwer Law International, Leiden, 1999) at 158). See also Pierre "On the Neutrality of Arbitrators and the Place of Arbitration” in Reymond and Bucher (eds) Swiss Essays on International Arbitration (Schulthess, Zurich, 1984) at 23-33.

94 Permanent Court of Arbitration <pca-cpa.org > (26 October 2014).

95 Gary Born International Commercial Arbitration Vol I (Kluwer Law International, New York, 2009) at 72-73.

96 Gary Born International Commercial Arbitration Vol I (Kluwer Law International, New York, 2009) at 73. 
SMEs in cross-border trade. The BAT constitutes a tool to enhance effective justice for SMEs. In addition, by doing so the BAT will, as research so far suggests, enhance cross-border trade and thereby will benefit New Zealand overall. While the New Zealand justice system is widely considered to be extremely effective, other trading partners with whom New Zealand business may wish to trade do not have the benefit of such a reputation. Entry by China or India into a BAT with New Zealand, for example, would illustrate a commitment on the part of those nations to international trade, and to the fair and effective resolution of disputes. ${ }^{97}$ Such an assurance would likely see an increased willingness on the part of New Zealand SMEs to trade with businesses located in those countries.

The benefits of the BAT are generally benefits of arbitration itself. Arbitration already serves as a preferred dispute resolution mechanism for those engaged in international trade, ${ }^{98}$ and has established itself as a serious alternative to international litigation over the last 30 years. ${ }^{99}$ The 2006 Queen Mary survey found that for most businesses selecting arbitration, their reasons for choosing it are usually flexibility of procedure, the enforceability of awards, the privacy and confidentiality, and the ability of parties to play some role in selecting the arbitrator(s). ${ }^{100}$ So while the idea of the BAT may seem relatively novel, the solution it provides is tested and trusted.

\section{B. The "But": Denial of Access to Justice}

Born identifies "access to the courts" or "due process" as one of the main obstacles that implementation of the BAT might face. ${ }^{101}$ As has been noted, the BAT removes many of the impediments to effective access to justice. However, an argument can be made that this improvement comes at a cost of the other facet of the right to access of justice: the right of access to a court.

97 See, for example, in regard to issues surrounding the enforcement of judgments in China: Wenliang Zhang "Recognition and Enforcement of Foreign Judgments in China: A Call for Special Attention to Both the "Due Service Requirement" and the "Principle of Reciprocity" (2013) 12 Chinese Journal of International Law 143; Zhang Shouzhi, Xu Xiaodan, Li Xiang "Forum Shopping for Dispute Resolution: Hurdles and Solutions" (January 2010) $<$ www.kingandwood.com>.

98 The Queen Mary survey found that for those businesses engaged in international trade, arbitration is ranked first more often than any other dispute resolution mechanism as the preferred mechanism for resolving disputes. See PwC and Queen Mary, University of London "International arbitration: Corporate attitudes and practices" (2006) $<$ http://www.pwc.be/en_BE/be/publications/ia-study-pwc-06.pdf > at 2.

99 Gaillard and Savage above n 94, at 2; Alan Redfern and others Redfern and Hunter on International Arbitration (5th ed, Oxford Univeristy Press, Oxford, 2009) [1.03]; Born, above n 97, at 2; Russell Weintraub International Litigation and Arbitration (5th ed ed, Carolina Academic Press, Durham, 2006) 605. See also Mitsubishi Motors Corp v Soler Chrysler-Plymouth, Inc, 473 US 614 (1985).

100 PwC and Queen Mary, University of London "International arbitration: Corporate attitudes and practices” (2006) <http://www.pwc.be/en_BE/be/publications/ia-study-pwc-06.pdf> at 2.

101 Gary Born, “BITS, BATS and Buts” (Kiev Arbitration Days 2012, Kiev, 15, 16 November 2012). The authors note that in addition to the right to "access to justice" the BAT raises issues in regard to the right to a "public" hearing (protected under s 14 BORA) due the proposed confidential nature of arbitral hearings (art 4(2) Draft BAT. Section 14 BORA will not be addressed in this article due to space constraints. 


\section{The right to natural justice}

Because the BAT serves to alter the rights of parties in terms of their options for a forum in which to access justice, ${ }^{102}$ on its face it engages issues with constitutional guarantees of access to natural justice as set out in ss 27(1) and (2) BORA. The explicit right to access to a court as stated in some constitutions ${ }^{103}$ cannot be found in s 27 BORA. The right to access to a court or tribunal under s 27 BORA is couched instead as affirming the requirement for decision-makers to act in accordance with certain procedures that are considered fundamental to the rule of law. These rights are concerned with ensuring that decision-makers follow correct procedures rather than arrive at fair outcomes. ${ }^{104}$ There are no equivalent provisions to be found in the International Conventions or bills of rights employed elsewhere. ${ }^{105}$

Adopting a broad interpretation, as stipulated by Noort, ${ }^{106}$ "tribunal" in s 27(1) BORA encompasses any body established by law making a determination as to a "person's rights, obligations, or interests protected or recognised by law". "Determination" has been held to "ha[ve] an adjudicative sense”. ${ }^{107}$ Arbitrators have been held to have a quasi-judicial function, ${ }^{108}$ and a tribunal established by virtue of the BAT would be (a) established by law and (b) poses a mandate to make a determination in regard to parties' obligations arising out of their business dealings. An arbitral tribunal established under the BAT would therefore constitute a tribunal for the purposes of $\mathrm{s} 27$. Accordingly, BORA applies to the tribunal.

The relevant obligations established by s 27 are (a) a requirement that tribunals observe the "principles of natural justice" 109 and (b) a requirement that decisions of tribunals be subject to "judicial review". 110

102 See above Part II C.

103 For example, art 19 IV Basic Law and art 29 Constitution of Guatemala.

104 Ministry of Justice "The Guidelines on the New Zealand Bill of Rights Act 1990: A Guide to the Rights and Freedoms in the Bill of Rights Act for the Public Sector" <www.justice.govt.nz> s 27.

105 Ministry of Justice "The Guidelines on the New Zealand Bill of Rights Act 1990: A Guide to the Rights and Freedoms in the Bill of Rights Act for the Public Sector" $<$ www.justice.govt.nz> s 27.

106 Ministry of Transport $v$ Noort [1992] 3 NZLR 260, 278 (CA). See also A Butler and P Butler The New Zealand Bill of Rights Act: A Commentary (LexisNexis, Wellington, forthcoming 2015) [25.3.9]; see also Paul Rishworth et al The New Zealand Bill of Rights (Oxford University Press, Auckland, 2003) 754, 755; Taito v R [2003] 3 NZLR 577 (PC) [20]; Lithgow v United Kingdom Application no 9006/80; 9262/81; 9263/81;9265/81; 9266/81; 9313/81; 9405/81 (8 July 1986) [201]: “'tribunal' may comprise a body set up to determine a limited number of specific issues, provided always that it offers the appropriate guarantees”.

107 Chisholm v Auckland City Council (CA 32/02, 29 November 2002); A Butler and P Butler The New Zealand Bill of Rights Act: A Commentary (2nd ed, LexisNexis, Wellington, forthcoming 2015) at 25.2.19.

108 Jivraj v Hashwani [2011] WLR 1872; [2011] UKSC 40 (SC) [41] per Clarke LJ.

109 New Zealand Bill of Rights Act 1990, s 27(1).

110 New Zealand Bill of Rights Act 1990, s 27(2). 
(a) Tribunals must observe the "principles of natural justice"

The BAT arbitration regime meets the standard of natural justice as required by s 27(1) BORA.

As stated above, what amounts to natural justice "has not been the subject of any sustained judicial analysis." 111 The White Paper notes that s 27(1) largely reflects basic principles of the common law - audi alteram partem and nemo judex in causa sua ${ }^{112}$. However, the principles will have a varying application in differing circumstances: ${ }^{113}$ The more serious the matter, the closer the procedures adopted will need to approximate the protections in ss 23 to 26 of BORA. ${ }^{114}$ In Ali $v$ Deportation Review Tribunal Elias J was of the view that "[t]he more significant the decision the higher the standards of disclosure and fair treatment [required].”115 Examples in which New Zealand courts have found a violation of natural justice include the fixing of substantial costs without giving both parties an opportunity to present submissions to the Court; ${ }^{116}$ a failure to provide a reasonable time to be heard; ${ }^{117}$ or significant delays in making a decision. ${ }^{118}$ The Ministry of Justice Guidelines consider the following requirements as essential for policy or legislation not to infringe the ambit of s 27(1) BORA, (ie to satisfy the requirements of natural justice): ${ }^{119}$

Prior notice - procedures to ensure that anyone whose rights or interests may be affected by a decision will have sufficient notice of that impending decision or hearing and be given adequate opportunity to prepare and present their case. ${ }^{120}$

Opportunity to be heard - all parties to a dispute should have the right to be heard by the decision-maker. ${ }^{121}$

111 A Butler and P Butler The New Zealand Bill of Rights Act: A Commentary (2nd ed, LexisNexis, Wellington, forthcoming 2015) at 25.2.4.

112 Paul Rishworth et al The New Zealand Bill of Rights (Oxford University Press, Auckland, 2003) 754.

113 G Palmer “A Bill of Rights for New Zealand: A White Paper” [1984-1985] I AJHR A6, 10.168.

114 New Zealand Bill of Rights Act 1990, ss 23-26: rights of persons arrested or detained, right of persons charged, minimum standards of criminal procedure, retroactive penalties and double jeopardy, respectively.

115 [1997] NZAR 208 at 220 (HC); see also Law Commission Law of Civil Penalties, Civil Pecuniary Penalties (Issues Paper 33, Wellington, 2012) at 5.28; A Butler and P Butler The New Zealand Bill of Rights Act: A Commentary (2nd ed, LexisNexis, Wellington, forthcoming 2015) 25.2.12.

116 Matthews v Marlborough District Council [2000] NZRMA 451 (HC).

117 Ali v Deportation Review Tribunal [1997] NZAR 208, 220 (HC).

118 Unitech Institute of Technology v Attorney-General (HC Wellington CIV 2005-485-89) 7 July 2005 per Miller J. See a comprehensive list of decisions up to 2005 in A Butler and P Butler The New Zealand Bill of Rights Act 1990: A Commentary (2nd ed, LexisNexis, Wellington, forthcoming 2015) 25.2.5.

119 Ministry of Justice "The Guidelines on the New Zealand Bill of Rights Act 1990: A Guide to the Rights and Freedoms in the Bill of Rights Act for the Public Sector" <www.justice.govt.nz> (last accessed 20 June 2014) s 27.

120 Waitemata Health v AG [2001] NZFLR 1122, (2001) FRNZ 216 (CA). 
Warnings as to adverse credibility findings - parties have to be warned of any pending adverse findings in order to provide an opportunity for the affected party to respond. $^{122}$

Legal representation - opportunities for persons to be represented at public tribunals have to be provided.

Cross-examination - natural justice generally requires the right of a person to cross-examine or test the evidence of the other side, especially in circumstances where credibility is an issue.

Reasons for decisions - reasons for the decisions have to be provided to the affected party. ${ }^{123}$

Declare potential conflict - members of decision-making panels or bodies have to declare potential conflicts of interest on appointment to office.

Overall from the above case law and commentary it can be deduced that natural justice is to be interpreted along the traditional "process and procedure" protection. $^{124}$

Fisher J in Methanex Motunui Ltd v Spellman observed that "[a]rbitration is a process by which a dispute is determined according to enforceable standards of natural justice.” ${ }^{125}$ Under the UNCITRAL Rules which are mooted as the applicable procedural rules and the $\mathrm{BAT}^{126}$ disputing parties must communicate notice of any arbitration. Furthermore, art 17(1) of the UNCITRAL Rules affirms the obligations of the tribunal to treat the parties equally, to give the parties reasonable opportunity to present their case, and to conduct the proceedings so "as to avoid unnecessary delay and expense and to provide a fair and efficient process for resolving the parties' dispute". ${ }^{127}$ These instructions to the arbitral tribunal are akin to the basic fair trial guarantees set out in ss 23 to 26 BORA and are in line with the Ministry of Justice Guidelines set out above. The UNCITRAL Arbitration Rules also provide how to deal with bias and challenge of an arbitrator ${ }^{128}$ and require that the tribunal provide reasons for its award. ${ }^{129}$

The BAT and the applicable UNCITRAL Arbitration Rules therefore meet the standard of natural justice so far promulgated by case law and commentary.

121 See Franic $v$ Wilson \& Anor [1993] 1 NZLR 318 (HC) and Upton v Green \& Anor (No 2) [1996] 3 HRNZ 179.

122 See Re Erebus Royal Commission [1983] 1 NZLR 662 (PC).

123 See Lewis $v$ Wilson and Horton Ltd [2000] 3 NZLR 546 (CA).

124 Paul Rishworth et al The New Zealand Bill of Rights (Oxford University Press, Auckland, 2003) 757; A Butler and P Butler The New Zealand Bill of Rights Act 1990: A Commentary (2nd ed, Lexis Nexis, Wellington, forthcoming 2015) 25.2.11.

125 Methanex Motunui Ltd v Spellman [2004] 1 NZLR 95 (HC) at [50].

126 Draft BAT, art 2.1(b).

127 UNCITRAL Arbitration Rules, art 17(1)

128 UNCITRAL Arbitration Rules, art 11 to 13.

129 UNCITRAL Arbitration Rules, art 34(3). 


\section{(b) Decisions of tribunals should be subject to "judicial review"}

One of the hallmarks of arbitration, and a factor equally applicable under the BAT are the extremely circumscribed rights of review of arbitral awards. ${ }^{130}$ In the authors' view, the limit the BAT places on the right to judicial review is justified.

"Judicial review" should be interpreted widely. It is shorthand for applications for relief. ${ }^{131}$ Under the BAT the arbitral tribunal will issue a decision that finally resolves some or all of the claims asserted in an International Commercial Dispute. ${ }^{132}$ Under the BAT a review of an arbitral award will be possible only at the point of enforcement, and even then there will be no ability for a review of the substance of the award. State courts may refuse to recognise and enforce an arbitral award where there are procedural deficiencies, including defective notice, illegality in the constitution of the tribunal; where the award concerns matters beyond the scope of the arbitration; or where the matter is contrary to the public policy in the state concerned.

The limited circumstances of review, particularly the lack of the review of the merits, prima facie constitutes a breach of s 27(2). The limited circumstances under which an award may be refused recognition and enforcement are more narrow than the possible scope of the broad, “[un]technical” sense provided by s $27(2) .{ }^{133}$

This breach, however, is a justified limit pursuant to s 5 of BORA. Tipping $\mathrm{J}$ set out the test to be applied to ascertain whether the limit placed on s 27(2) is justified in a free and democratic society in Hansen $v R^{134}$

(1) does the limiting measure serve a purpose sufficiently important to justify curtailment of the right or freedom?

(2) (a) is the limiting measure rationally connected with its purpose?

(b) does the limiting measure impair the right or freedom no more than is reasonably necessary for sufficient achievement of its purpose?

(c) is the limit in due proportion to the importance of the objective?

The BAT guarantees the other facet of access to justice: effective justice. The aim of the BAT is to promote international trade and investment by providing

130 See above at III A 1 and III A 3.

131 A wide interpretation is not only in line with the interpretation principles set out in Noort but is also supported by the underlying natural justice requirement ("Review process - need for an independent decision-making body or office whereby a person affected can challenge the decision" Ministry of Justice "The Guidelines on the New Zealand Bill of Rights Act 1990: A Guide to the Rights and Freedoms in the Bill of Rights Act for the Public Sector" <www.justice.govt.nz> (20 June 2014) s 27. See also Cooke P in Burt v Governor-General [1992] 3 NZLR 672, 679 (CA) who doubted that the expression "judicial review" is used in any technical sense. A Butler and P Butler The New Zealand Bill of Rights Act: A Commentary (2nd ed, LexisNexis, Wellington, forthcoming 2015) 25.3.11. et seq.

132 Draft BAT, art 1 “Arbitral Award” and art 6(1) "Each Party, including the Courts of each Party, shall recognize Arbitral Awards made by an arbitral tribunal pursuant to Articles 2, 3 and 4 of this Treaty as final and binding.”

133 Burt v Governor-General [1992] 3 NZLR 672 (CA) at 679 per Cooke P.

134 Hansen $v$ R [1997] 3 NZLR 1, [2007] NZSC 7 at [104] per Tipping J. 
a means for the effective and fair resolution of disputes by providing access to neutral, efficient and fair means of international dispute resolution. This aim is sufficiently important to justify curtailment of the s 27(2) BORA right.

The limitations are rationally connected to the purpose of fostering cross-border trade. Limiting avenues of review improves the degree of finality of an arbitral award. In turn, this improves the certainty with which business, especially SMEs, can approach cross-border trade.

The limitation of the grounds of review of an arbitral award under the BAT does not limit the right to judicial review more than is reasonably necessary. While the grounds for review may be more limited than those available in a domestic court, it is generally justifiable to confine parties to particular appeal rights. ${ }^{135}$ In this case the limitations do not affect an SME's ability to seek review in relation to essential elements of natural justice, or matters of legality and public policy of the state. The limitations increase commercial certainty while upholding the purpose of s 27(2) - that a business can ensure that a decision "has been carried out lawfully". ${ }^{136}$ The scope of review could not be expanded without compromising the policy goals of the BAT: the less circumscribed the right of review, the greater the costs of cross-border dispute resolution (and consequently the less accessible the justice). Furthermore, consistent with the default nature of the BAT, businesses are free to agree on grounds of review. $^{137}$

The limitation of the grounds of review of an arbitral award under the BAT is proportionate to the importance of the objective. Review is available in relation to essential elements of natural justice, or matters of legality and public policy of the state in accordance with the New York Convention. Businesses may opt to use the domestic courts to preserve broader avenues of review, or establish a procedure for review within the framework of the BAT.

\section{Summary}

When balancing the right to effective justice with the right to access to justice in regard to the ability under s 27(2) BORA for judicial review the balance should lie with the BAT and the BAT's advancement of effective justice in international trade. Access to the courts is not an unlimited right. ${ }^{138}$ The right to access to the courts is hollow if barriers prevent parties from effectively gaining that access. Because the BAT fosters access to justice it is a justified limitation on the right to access to the courts. The conclusion is also in line with the jurisprudence of the ECtHR in regard to art 6 European Convention

135 A Butler and P Butler The New Zealand Bill of Rights Act: A Commentary (2nd ed, LexisNexis, Wellington, forthcoming 2015) at 25.3.9.

136 Ministry of Justice, “The Guidelines on the New Zealand Bill of Rights Act 1990: A Guide to the Rights and Freedoms in the Bill of Rights Act for the Public Sector" $<$ www.justice.govt.nz> s 27.

137 See, for example, art 5(1) of the Second Schedule to the Arbitration Act 1996. Parties could not, however provide for a review of facts.

138 Compare also Danone Asia Pacific Holdings Pte Ltd v Fonterra Co-Operative Group Ltd [2014] NZHC 1681 at [54] per Venning J: "Parties do not enjoy an unfettered right to access to the Courts" 
on Human Rights 1950 ("ECHR") which provides, at least on a textual reading, a more comprehensive protection in regard to access to justice than is provided for by s 27 BORA. Lithgow $v$ United Kingdom ${ }^{139}$ concerned the establishment of the Aircraft and Shipbuilding Industries Tribunal, by an Act of Parliament, to decide upon matters in regard to the settlement of disputes concerning compensation arising from nationalisation measures. Lithgow claimed that since he could only plead for compensation in front of the arbitral tribunal that his right to access of justice under art 6 was infringed. The ECtHR found no infringement of art 6(1) ECHR since the arbitral tribunal was established by law, provided all the appropriate guarantees of a neutral and fair decision-maker, and the government had a margin of appreciation of how to regulate access to the courts. ${ }^{140}$

The analysis advanced in this article is also not invalidated by the 2011 decision of the Guatemalan Constitutional Court in regard to art 2(3) of the Guatemalan Arbitration Law. ${ }^{141}$ Article 2(3) of the Arbitration Law stated: ${ }^{142}$

The controversies that arise derived from the application, interpretation and execution of international contracts between private parties shall be resolved by the norms contained in the Rules of Arbitration of the Court of Arbitration (sic) of the International Chamber of Commerce, unless the parties agree expressly on their submission to another arbitration forum.

The Constitutional Court struck down the provision holding that it violated the due process clause of art 12 of the Constitution by imposing arbitration on private parties and disregarding party autonomy. ${ }^{143}$ The Court also found that the provision infringed the art 29 right of access to state courts ${ }^{144}$.

Art 2(3) of the Arbitration Law was different from the BAT in one key respect: it did not allow parties to opt out of arbitration, only select the rules of

139 Application no 9006/80; 9262/81; 9263/81;9265/81; 9266/81; 9313/81; 9405/81) (8 July 1986).

140 Lithgow v United Kingdom (Application no. 9006/80; 9262/81; 9263/81;9265/81; 9266/81; 9313/81; 9405/81) (1986) at [194]-[197]; see also Stretford $v$ The Football Association Ltd \& Anor [2007] EWCA Civ 238, [2007] 2 All ER (Comm) 1 and Sumukan v Commonwealth Secretariat [2007] EWCA Civ 243, [2007] 3 All ER 342 where the Court in both cases held that a voluntary waiver of access to court in favour of arbitration proceedings was compatible with art 6 (right to an impartial tribunal), but that some art 6 rights might be harder to waive than other rights.

141 The US, the Dominican Republic and the Central American countries concluded the DR-CAFTA - US Free Trade Agreement in the year 2004. Guatemala enacted its implementation norms by way of the Law for the Implementation of the DR-CAFTA - US Free Trade Agreement (Decree 11-2006 of the Guatemalan Congress). Article 117 of the said law added a third paragraph to article 2 of the Arbitration Law.

142 "Las controversias que surjan derivadas de la aplicación, interpretación y ejecución de las contrataciones internacionales entre privados, se resolverán de acuerdo a las normas contenidas en el Reglamento de Arbitraje de la Corte de Arbitraje de la Cámara de Comercio Internacional, salvo que las partes acuerden expresamente el sometimiento a otros foros de arbitraje”.

143 Inconstitucionalidad General Parcial, Expediente 387-2010 (7 July 2011) 9 et seq.

144 Inconstitucionalidad General Parcial, Expediente 387-2010 (7 July 2011) 9 et seq. 
a different arbitral institution to that specified by the law. Such a limitation manifests too great a disregard for party autonomy to be justifiable.

\section{CONCLUSION}

At present, internationally contracting parties are free to decide on a dispute resolution mechanism. What both case law ${ }^{145}$ and anecdotal evidence suggest is that more often than not international contracts do not contain a clause prescribing a dispute resolution mechanism (or they contain a non-exclusive forum selection clause). In the event of a dispute, and assuming no express agreement to the contrary, SMEs will find themselves subject to international litigation.

The current system of international dispute resolution - default international litigation - is especially unsatisfactory for SMEs and creates a barrier for them to access justice in an international dispute. Its cost, complexity, rigidity and uncertainty and the consequent issues in terms of access to justice have an adverse effect on international trade. The SMEs, their communities and the economy more generally suffer as a result.

A Bilateral Arbitration Treaty will enable parties to resolves disputes quickly, flexibly, expertly, and in a manner that both parties are trustful of, and which gives effect to their expectations relating to the resolution of disputes. A BAT will give SMEs access to justice in the international space. In so doing, it would serve to encourage international trade.

145 See, for example, Bomac Laboratories Ltd v Life Medicals (CIV 2010-404-004654) 5 August 2011, HC Auckland, Abbott AJ. 


\title{
DRAFT MODEL BILATERAL ARBITRATION TREATY*
}

\author{
TREATY BETWEEN
}

THE GOVERNMENT OF [State A]

AND THE GOVERNMENT OF [State B]

CONCERNING THE PROMOTION OF TRADE

\section{AND ENCOURAGEMENT OF RECIPROCAL INVESTMENT}

The Government of [State A] and the Government of [State B] (hereinafter the "Parties");

Desiring to promote greater economic cooperation between them with respect to cross-border trade and investment between enterprises of one Party and enterprises of the other Party; ${ }^{146}$

Bearing in mind the possibility that from time to time disputes may arise in connection with such cross-border trade and investment; ${ }^{147}$

Recognizing the importance of providing means of effectively and fairly resolving disputes with respect to such cross-border trade and investment; ${ }^{148}$

Recognizing that a stable legal framework and access to neutral, efficient and fair means of international dispute resolution will promote the rule of law and will maximize effective utilization of economic resources; ${ }^{149}$

Recognizing the benefits of arbitration as a method of settling disputes arising in the context of international trade and investment; ${ }^{150}$

Have agreed as follows:

\section{Article 1: Definitions}

For purposes of this Treaty:

“Arbitral Award” means a decision finally resolving some or all of the claims asserted in an International Commercial Dispute, in writing and signed by an arbitrator or arbitrators, in an arbitration under this Treaty.

* $\quad$ Gary Born, partner, Wilmer Cutler Pickering Hale and Dorr LLP , 19 June 2014

146 Adapted from Preamble 2012 U.S. Model BIT.

147 Adapted from Preamble to the ICSID Convention.

148 Adapted from Preamble to U.S. Model BIT.

149 Adapted from Preamble to U.S. Model BIT.

150 Taken from UN General Assembly Resolution 40/72 (11 December 1985), in relation to adoption of the UNCITRAL Model Law on International Commercial Arbitration. 
“Claimant" means an Enterprise of a Party that is party to an International Commercial Dispute that has initiated or intends to initiate an arbitration under this Treaty.

“Court” means any judicial organ, administrative or other government tribunal, or any other body that exercises any adjudicative, judicial, or similar governmental authority delegated to it by that Party.

“Enterprise” means any legal or juridical entity constituted or organized for profit, including a corporation, company, limited partnership, trust, partnership, sole proprietorship, joint venture, association, or similar organization, whether owned by private persons, private or governmental enterprises, or state or governmental bodies or entities. ${ }^{151}$

“Enterprise of a Party” means an Enterprise constituted or organized under the law of a Party, including a branch of any Enterprise (regardless of where it is constituted or organized), [carrying out business activities in the Territory of such Party].

“International Commercial Dispute” means a dispute, disagreement or controversy:

(a) arising between (1) Enterprises of a Party; and (2) Enterprises of the other Party; and

(b) arising out of commercial contracts, transactions, or activities, including, without limitation: any trade transaction for the supply or exchange of goods or services; distribution agreement; commercial representation or agency; factoring; leasing; construction of works; consulting, engineering; licensing; investment; financing; banking; insurance; exploitation agreement or concession; joint venture and other forms of industrial or business cooperation; mergers or acquisitions; carriage of goods or passengers by air, sea, rail or road, and any other activities the nature or purpose of which is the realization of a profit. ${ }^{152}$ Notwithstanding the foregoing, an "International Commercial Dispute" does not include consumer disputes, employment or labor disputes, domestic relations disputes, marital or child custody disputes, inheritance disputes or [

“New York Convention” means the United Nations Convention on the Recognition and Enforcement of Foreign Arbitral Awards, done at New York, June 10, 1958.

"Notice of Dispute" means notice in writing by any party to an International Commercial Dispute, pursuant to Article 2(1)(a), that identifies the dispute and proposes the resolution of such dispute by good faith discussions.

151 Adapted from U.S. Model BIT, at 5.

152 Taken from UNCITRAL Model Law, Article 1(1), at fn. 2. 
"Notice of Arbitration" means notice in writing referring a dispute to arbitration pursuant to Article 2(1)(b) and the UNCITRAL Arbitration Rules.

“Respondent" means an Enterprise of a Party that is party to an International Commercial Dispute, and is not a claimant under this Treaty.

“Territory” means:

(a) with respect to [State A],

(b) with respect to [State B],

(c) with respect to each Party, the territorial sea and any area beyond the territorial sea of the Party within which, in accordance with customary international law as reflected in the United Nations Convention on the Law of the Sea, the Party may exercise sovereign rights or jurisdiction. ${ }^{153}$

“UNCITRAL Arbitration Rules” means the Arbitration Rules of the United Nations Commission on International Trade Law (adopted by GA Resolution 31/98 on 15 December 1976 and revised by GA Resolution 65/22 on 6 December 2010, with new article 1, paragraph 4 adopted by GA Resolution 68/109 on 16 December 2013, and as may be revised in the future). ${ }^{154}$

\section{Article 2: Arbitration of International Commercial Disputes}

1. Except as provided in Article 5(1) of this Treaty, all International Commercial Disputes shall be resolved as follows:

(a) an Enterprise of a Party which is involved in an International Commercial Dispute may give notice in writing to any Enterprise of the other Party which is involved in such International Commercial Dispute, identifying the dispute and proposing the resolution of such dispute by good faith discussions for a period of not less than thirty (30) days;

(b) if, thirty (30) days after receipt of a Notice of Dispute, the Enterprises of the Parties which are involved in an International Commercial Dispute have not amicably resolved such dispute, then either Enterprise may refer such dispute to arbitration by providing the other Enterprise with a Notice of Arbitration pursuant to the UNCITRAL Arbitration Rules;

153 Adapted from U.S. Model BIT, at 6

154 From General Assembly Resolution 68/109, 16 December 2013 (“Arbitration Rules (as revised in 2010, with new article 1, paragraph 4, as adopted in 2013)”); U.S. Model BIT, Definitions, at p. 6 (“'UNCITRAL Arbitration Rules' means the arbitration rules of the United Nations Commission on International Trade Law”. ) 
(c) any Arbitral Award in an arbitration pursuant to this Article 2 shall be subject to recognition and enforcement pursuant to Articles 6 and 7 of this Treaty.

\section{Article 3: Reference of International Commercial Disputes to Arbitration}

1. Except as provided in Article 5(1) of this Treaty, each Party, including the Courts of each Party, when seized of an International Commercial Dispute, shall, at the request of one of the Enterprises involved in such dispute, refer the dispute to arbitration pursuant to Articles 2 and 4 of this Treaty. ${ }^{155}$

2. Nothing in Articles 2, 3(1) and 4 of this Treaty shall prevent the Courts of the Parties from considering or granting requests for interim measures, in aid of arbitration, prior to the constitution of an arbitral tribunal under Articles 2 and 4 of this Treaty.

\section{Article 4: Arbitration Procedures}

1. Except as provided in Article 5(1) of this Treaty, any International Commercial Dispute referred to arbitration pursuant to Article 2(1)(b) or Article 3(1) of this Treaty shall be resolved, unless otherwise agreed in writing by the Enterprises involved in such dispute, as follows:

(a) the arbitration shall be conducted pursuant to the UNCITRAL Arbitration Rules;

(b) the appointing authority for the arbitration shall be [the Permanent Court of Arbitration];

(c) the number of arbitrators shall be [one] [unless in exceptional cases the Permanent Court of Arbitration concludes that three arbitrators would be appropriate];

(d) the seat of the arbitration shall be [designated by the arbitral tribunal];

(e) the language of the arbitration shall be [English];

(f) the arbitral tribunal shall use its best efforts to make a final award in the arbitration not later than [18 months] following constitution of the arbitral tribunal; and

(g) the arbitration shall be deemed to have commenced, and a claim shall be deemed to be submitted to arbitration, on the date on which the Notice of Arbitration is received by the respondent or respondents.

2. Unless otherwise agreed in writing between the parties, any arbitration pursuant to Articles 2 and 4 of this Treaty shall be confidential, and the

155 Adapted from Art II(3) of the NY Convention. 
Enterprises involved in such dispute shall keep confidential all materials submitted in or created for the purpose of the arbitration, all documents produced by another party in the arbitration not otherwise in the public domain, and all awards, orders and other communications in the arbitration, save and to the extent that disclosure may be required of a party by legal duty, to protect or pursue a legal right or to enforce or challenge an award in bona fide legal proceedings before a court, other judicial authority or arbitral tribunal. ${ }^{156}$

\section{Article 5: Dispute Resolution Agreements; Exclusion of Treaty}

1. Notwithstanding the provisions of Articles 2, 3 and 4 of this Treaty, an International Commercial Dispute shall not be referred to arbitration pursuant to Article 2(1)(b) or Article 3(1) of this Treaty if the Enterprises which are party to such dispute have expressly agreed in writing to:

(a) exclude application of this Treaty or arbitration pursuant to this Treaty of such dispute; or

(b) refer such dispute to arbitration pursuant to any institutional arbitration rules or otherwise, unless such agreement to arbitrate is compatible with Article 4(1) of this Treaty; or

(c) refer such dispute to any court or other judicial authority, in either one of the Parties or another State; or

(d) refer such dispute for final resolution to expert determination or any other form of alternative dispute resolution.

2. Notwithstanding the provisions of Articles 2, 3 and 4 of this Treaty, the Courts of a Party shall not be obliged to refer the Enterprises which are party to an International Commercial Dispute to arbitration pursuant to Article 3(1) of this Treaty until the expiration of any period of time during which such Enterprises have agreed in writing to attempt to resolve their disputes amicably, including by negotiations, conciliation, mediation or any similar process, prior to initiating arbitral proceedings.

3. Nothing in this Article 5 shall restrict the autonomy of the Enterprises which are party to an International Commercial Dispute to refer such dispute to arbitration pursuant to Articles 2, 3 and 4 of this Treaty after such dispute has arisen, regardless whether such dispute would otherwise be subject to arbitration under this Treaty.

\section{Article 6: Recognition and Enforcement of Arbitral Awards}

1. Each Party, including the Courts of each Party, shall recognize Arbitral Awards made by an arbitral tribunal pursuant to Articles 2, 3 and 4 of this

156 Adapted from LCIA Rules, Article30.1. 
Treaty as final and binding and enforce them in accordance with the rules of procedure of the Party in which the award is relied upon, under the conditions laid down in Articles 6 and 7 of this Treaty. ${ }^{157}$

2. Neither Party shall impose substantially more onerous conditions or higher fees or charges on the recognition or enforcement of Arbitral Awards made by an arbitral tribunal pursuant to Articles 2, 3 and 4 of this Treaty than it imposes on the recognition or enforcement of domestic arbitral awards, arbitral awards subject to the New York Convention, or judgments of any court. ${ }^{158}$

3. An Enterprise of a Party applying for recognition and enforcement of an Arbitral Award made by an arbitral tribunal pursuant to Articles 2, 3 and 4 of this Treaty shall, at the time of the application, or as otherwise permitted, supply: ${ }^{159}$

(a) a duly authenticated original Arbitral Award or a duly certified copy thereof;

(b) a duly certified copy of the Notice of Dispute referred to in Article 2(1) (a) of this Treaty and the Notice of Arbitration referred to in Article 2(1)(b) of this Treaty; and

(c) if the said Arbitral Award is not made in an official language of the country in which the award is relied upon, the party applying for recognition and enforcement of the award shall produce a translation of these documents into such language, certified by an official or sworn translator or by a diplomatic or consular agent. ${ }^{160}$

4. Both Parties declare their mutual desire and expectation that Arbitral Awards made by an arbitral tribunal pursuant to Articles 2, 3 and 4 of this Treaty be subject to recognition and enforcement by the courts of other States in accordance with the provisions of the New York Convention. For purposes of such recognition and enforcement proceedings, both Parties desire and expect that the provisions of Articles 2, 3 and 4 of this Treaty shall, subject to Article 5, be deemed to constitute a valid agreement to arbitrate between the Enterprises that are party to the International Commercial Dispute within the meaning of Articles II, IV and V(1)(a) of the New York Convention.

\section{Article 7: Refusal of Recognition and Enforcement of Arbitral Awards}

1. Recognition and enforcement of an Arbitral Award made by an arbitral tribunal pursuant to Articles 2, 3 and 4 of this Treaty may be refused, at

157 Article III of the New York Convention.

158 Article III of the New York Convention.

159 Modified from Article IV of the New York Convention.

160 Adapted from Article IV(2) of the New York Convention. 
the request of the Enterprise of a Party against whom it is invoked, only if that Enterprise furnishes to the court where the recognition and enforcement is sought, proof that: ${ }^{161}$

(a) where the arbitration was conducted pursuant to Articles 2, 3 and 4 of this Treaty, the Arbitral Award did not arise from an International Commercial Dispute under this Treaty or was not made in accordance with Articles 2, 3 and 4 of this Treaty; or

(b) the Enterprise of a Party against whom the Arbitral Award is invoked was not given proper notice of the appointment of the arbitrator or of the arbitration proceedings or was otherwise unable to present his case; or

(c) the Arbitral Award deals with a difference not contemplated by or not falling within the terms of the submission to arbitration, or it contains decisions on matters beyond the scope of the submission to arbitration, provided that, if the decisions on matters submitted to arbitration can be separated from those not so submitted, that part of the award which contains decisions on matters submitted to arbitration may be recognized and enforced; or

(d) the composition of the arbitral tribunal or the arbitral procedure was not in accordance with the agreement of the Enterprises that are party to the International Commercial Dispute, or failing such agreement, was not in accordance with the law of the country where the arbitral seat was located.

2. Recognition and enforcement of an Arbitral Award made by an arbitral tribunal pursuant to Articles 2, 3 and 4 of this Treaty may also be refused if the competent authority in the Party where recognition and enforcement is sought finds that:

(a) The subject matter of the difference is not capable of settlement by arbitration under the law of that Party; or

(b) The recognition or enforcement of the award would be contrary to the public policy of that Party.

\section{Article 8: Scope}

1. A Party's obligations under this Treaty shall apply to: ${ }^{162}$

(a) the Courts of a Party, including the Courts of any political subdivisions of a Party; and

161 Adapted from Articles V and VI of the New York Convention.

162 Art 2(2) U.S. Model BIT. 
(b) any governmental authority or organ of a Party, including any governmental authority or organ of any political subdivisions of a Party.

\section{Article 9: Entry into Force and Termination}

1. Each Party shall notify the other of the completion of the constitutional procedures required concerning the entry into force of this Treaty, ${ }^{163}$ which shall enter into force thirty (30) days after the date of receipt of the final notification. ${ }^{164}$

2. Each Party shall take steps, including by publication of the terms of this Treaty, to ensure that all Enterprises of such Party are aware of the provisions of this Treaty.

3. The Treaty shall be in force for an initial period of twenty (20) years. It shall remain in force thereafter, unless one of the Parties gives one year's written notice of termination through diplomatic channels. ${ }^{165}$

\section{[Article 10: Retroactivity]}

[This Treaty does not create retroactive obligations or responsibilities for any Party, ${ }^{166}$ and the provisions of this Treaty shall not apply to any International Commercial Dispute arising out of events which had occurred, or to claims which had arisen, prior to its entry into force. ${ }^{167}$ ]

IN WITNESS WHEREOF, the respective plenipotentiaries have signed this Treaty.

DONE in duplicate at [city] this [number] day of [month, year], in the English and [foreign] languages, each text being equally authentic.

FOR THE GOVERNMENT OF

[State A]

\section{FOR THE GOVERNMENT OF}

[State B]

163 Adapted from Article 11 of the 2006 France Model BIT.

164 Adapted from Article 22 of the U.S. Model BIT.

165 Adapted from Article 11 of the France Model BIT.

166 Adapted from Article 3(D) of the IISD Model Investment Agreement.

167 Adapted from Article XIII(2) of the 2010 UK-Columbia BIT. 